\title{
Consumer legal protection in the EU
}

\author{
Mária Dzúrová1,* \\ ${ }^{1}$ University of Economics in Bratislava, Department of Marketing, Dolnozemská cesta 1, Bratislava, \\ 85235 Slovak Republic
}

\begin{abstract}
Consumer protection is a very wide-ranging issue and needs to be given due attention. It concerns the safety of consumers in the environment of individual countries of the world, it concerns the consumer safety of certain groups, such as the European Union. The basic frameworks of consumer protection are set by the guidelines of world organizations - the $\mathrm{UN}, \mathrm{WHO}$, but also the European Union and individual member states. In the area of consumer protection, attention is paid to major health problems caused by unsuitable food, such as food scandals, various types of diseases - mad cow disease, swine fever, covid 19.
\end{abstract}

\section{European Union law and consumer}

An effective consumer protection policy guarantees the proper and efficient functioning of the single market. It aims to protect consumers' rights vis-à-vis traders and to provide enhanced protection to vulnerable consumers. The financial crisis has shown that consumer protection rules can make markets fairer and the quality of competition can improve. Empowering consumers and effectively protecting their security and economic interests have become key objectives of European policy

Article 4.2 letter (f) and Articles 12, 114 and 169 of the Treaty on the Functioning of the European Union (TFEU) and Article 38 of the Charter of Fundamental Rights of the European Union.

In order to promote the interests of consumers and ensure a high level of consumer protection, the Union shall contribute to protecting the health, safety and economic interests of consumers, and to promoting their right to information, education and the formation of associations for the protection of their interests."

The EU's agenda for consumer policy consists mainly of the European Consumer Program and the Consumer Program 2014-2020.

The Consumer Agenda has various objectives:

- promote consumer safety through the 2013 Product Safety and Market Surveillance Package, and in particular through better product identification and traceability, measures to strengthen safety in the food chain and the new rules on cosmetic product safety introduced in mid-2013,

\footnotetext{
* Corresponding author: maria.dzurova@euba.sk
} 
- raise awareness of consumer rights: Interactive tools have been developed, such as the Consumer Classroom, to inform and educate consumers and help them fully participate in the single market.

- strengthen the enforcement of consumer protection rules through coordinated action against breaches of EU consumer law through website inspections by a network of national consumer protection authorities; and simple, fast and inexpensive out-of-court redress procedures for consumers, available through the Alternative Dispute Resolution Directive (2013) and the Online Consumer Dispute Resolution Regulation (2013),

- integrate consumer interests into key sectoral policies through new legislation in sectors such as telecommunications, digital technologies, energy, transport and food, and new measures to increase transparency and access to retail financial services and facilitate the transfer of bank accounts.

Strengthening consumer protection, which is a key objective of the EU Consumer Policy Strategy set in the Commission Staff Working Document on Strengthening EU Consumer Rights, aims to empower EU consumers through consumer choice, information and awareness.

\section{Examining consumer behaviour}

The Consumer Agenda identifies challenges, such as moving towards more sustainable consumption and addressing the specific needs of vulnerable consumers.

The Consumer Program 2014-2020, with a budget of $€ 188.8$ million, will support EU consumer policy for the coming years. It aims to help citizens enjoy their consumer rights and participate actively in the single market, thus fostering growth and innovation and helping the EU meet the Europe 2020 goals.

The Consumer conditions scoreboard monitors the consumer environment across Europe through three key dimensions: knowledge and trust; compliance and enforcement; complaints and dispute resolution. It also examines progress on the EU Digital Single Market from a consumer perspective

The consumer conditions scoreboard is based mainly on surveys of consumers' and retailers' attitudes towards cross-border trade and consumer protection.

It monitors national conditions for consumers in three areas

- knowledge and trust

- compliance and enforcement

- complaints and dispute resolution.

The conditions scoreboard also examines progress in the integration of the EU retail market and the uptake of e-commerce.

\section{Product health and safety}

European consumer protection measures are aimed at protecting the health, safety and economic and legal interests of European consumers, wherever they live, reside or shop in the EU. EU provisions govern both physical transactions and e-commerce and contain general rules, together with provisions for specific products, including medicines, genetically modified organisms, tobacco products, cosmetics, toys and explosives. 
The basis is to ensure that all consumers in the Union, wherever they live, reside or shop in the EU, enjoy a high common level of protection against risks and threats to their security and economic interests, and increase consumers' opportunities in defending their own interests.

Consumer safety and health is essential for a healthy life. For this reason, high attention is paid to this issue in the EU environment. Directive 2001/95/EC introduced a system of general product safety. On the basis of this basis, all consumer products placed on the market must meet certain standards. These include information for consumers, measures to prevent threats to safety, monitoring product safety and traceability. Clearly even if they are not covered by specific sectoral legislation. Where a product poses a serious threat requiring urgent action, the Member State concerned shall immediately inform the Commission through THE RAPEX system, which is intended for the rapid exchange of information between the Member States and the Commission. When Slovakia joined the EU, we did not have dangerous products on the market. Over time, the situation has changed. Some have emerged in the Union environment, others have appeared on the Slovak market. The supervisory authorities shall comply with the information obligation for EU Member States. It is a paradox that products intended for children, i.e. a vulnerable group of consumers, and toys, often appear in the rapid information system. Therefore, separate directives are processed for areas where the rules are most frequently violated.

\section{Consumer food safety}

The objectives of European food safety policy are: protecting human health and consumer interests and promoting the smooth functioning of the Single European Market. The EU therefore ensures the establishment and compliance of control standards in the areas of feed and food hygiene, animal and plant health and the prevention of contamination of food by external substances. The Union also regulates the labelling of food and feed.

Food safety in the EU has undergone major changes at the beginning of the current millennium. This was due to shortcomings in both food and animal feed. This was an epidemic of BSE and dioxin threat and various food scandals. An approach called 'from farm to table', i.e. supply chain, has been established. It assumes and guarantees a high level of food safety at all levels of the chain. Thus, from the process of production and distribution of all food products marketed in the EU, regardless of whether they were produced in the EU or imported from third countries. It is a set of legislation which is a comprehensive and integrated system of rules applicable to the entire food chain. This means from feed and health to plant protection and food production to processing, storage, transport, import, export up to the retail sale.

In the case of various mediated food scandals, there is also an interest in consumers finding out why such a situation has occurred. Consumers begin to pay attention to the information on packaging, they begin to notice the country of origin of the product. They will start to consider how and where to obtain information on the quality of the products they buy, the country of origin is suddenly very important. Thus, in the environment of Slovakia, there is a reservation on food from Poland after the mediated scandals. Otherwise, consumers are not very interested in the issue of their own protection.

The EU pays sufficient attention to food law. It sets framework regulations declaring general principles and requirements relating to food and feed law. The precautionary principle applies. The Regulation specifies the risk assessment approach and the general provisions on the traceability of food and feed. In principle from field to table, this means that if in any way the unsuitability of a food for human use is detected the Rapid Alert System for Food and Feed, RASFF, is activated. This system also allows Member States, as well as the 
Commission, to exchange information quickly and coordinate responses to health threats caused by food or feed.

The main idea was the establishment of the European Food Safety Authority (EFSA). This accident evaluates the risks associated with the food chain. And, of course, he informs the public about them. In some cases, current food law is assessed, depending on the different risks, confronts scientific studies and efforts are made to improve cooperation with Member States in providing experts and providing data. Regulations on novel foods, regulations on GMOs, pesticides, food contact materials and food ingredients are being examined in order to bring them into line with the review of general food law and to increase transparency. This is critical to the general security of the population.

Food hygiene is an important part of food safety entering the EU market. For this reason, legal measures and guidelines for food hygiene have been adopted in this area. Food hygiene rules deal with specific hygiene rules for foodstuffs of animal origin. The Community declares official controls on animal products intended for human consumption. This means that specific rules are laid down for fresh meat, bivalve mollons, milk and milk products. The set of rules imposes responsibility for food hygiene directly on the various actors in the food chain. This is using a self-regulatory system that uses the HACCP (hazard analysis and critical control points) method, which is monitored by official controls. Official controls must be carried out by the competent authorities.

The legal framework on food labelling is designed to guarantee consumers access to clear, comprehensible and reliable information on the content and composition of products in order to protect their health and best interests. For example, allergens such as soya, gluten or lactose must be clearly indicated on the packaging.

The provision of information is an important and important piece of information in the protection and safety of food for the consumer. As of 2016, the regulation has declared the information that the manufacturer must comply with and place on the packaging of products - i.e. food that enters the market. The basis is the presence of allergens in unpackaged foods, i.e. in restaurants and canteens, the origin of unprocessed meat. There was already an obligation to indicate the country of origin and the presence of imitation foodstuffs, such as plant products replacing cheese or meat. A separate chapter is the country of origin in food. Member States shall specify in the provisions on designation of origin the requirements (with certain exceptions) for the indication of the place of rearing and the place of slaughter of packaged fresh, chilled and frozen pig, mutton, goat's and poultry meat.

The rules prohibit misleading consumers, including all information. I mean, advertising and presenting food. The rules for permitted nutrition and health claims apply. For example, "low fat" or "high fiber" or statements about the relationship between food and health. All claims must be supported by scientific evidence contained in the EU public register.

It is important to respect groups of vulnerable consumers in the market that have their specific needs. Specific groups of vulnerable consumers are infants and young children, persons with special health problems and people on a reduced energy-reduced diet for weight control. Strict rules apply to food and vulnerable consumers

In recent years, there have been many activities and complaints about double quality food on the eastern European countries market. Various checks, surveys show that products also on the Slovak market are less valuable, their composition is not the same throughout Europe. This applies to food primarily, but also to drugstore goods. The declaration of differential quality of products with the same brand name and from the same manufacturer has led to changes in the rules. The Consumer Protection Directive also found in prohibited commercial practices that products must be correctly labelled. Double quality is prohibited and is considered a prohibited commercial practice. In order to be able to prove double quality, in particular for foodstuffs, it is necessary to follow the correct sampling procedures - i.e. one producer, one batch, one day. And so assess the difference in quality. However, since this is 
classified as a prohibited commercial practice, such situations of different quality on the European market must not occur.

\section{Conclusion}

Health policy is a very wide area. It deals with the normal commercial relationship of the consumer-trader. The legislation regulates the safety and quality of food as well as the safety and quality of ordinary non-food products. Many issues are solved through the European Consumer Centre. There is an agenda of vulnerable consumers who have specific needs and the possibilities of harming them are many. The protection of the economic interests of consumers is important. The alternative solution of consumer disputes is one way of shortening the resolution of consumer problems, which can only be dealt with in our courts. A separate chapter is financial literacy and consumers' ability to solve their economic problems.

The EU contributes to the achievement of the consumer protection objectives by measures taken to approximate the provisions of the laws, regulations and administrative provisions of the Member States in order to complete the creation of the internal market. One of the EU Member States' means of consumer protection is the European Consumer Programme Promoting Confidence and Growth. The consumer is the most numerous market operator, but it is not organised. This means that it is not strong in its own defence against the unfair commercial practices it encounters in some areas. This implies that increased attention should be paid to targeted education and consumer information in each area. Consumers need to learn not only to know their own rights, but also to use them. Raise awareness for your own safety. To follow different campaigns, such as food or a healthy lifestyle, it is necessary to distinguish the plausibility of information that the consumer receives from different media. And without which, for example, he can't make the right decision.

\section{References}

1. D. Vokounová, Current ConsumerBuying Behavior. Application of knowledge in process of business dynamization in CentralEurope : theproceedings of the 5th internationalscientificconference on trade, international business and tourism : 16. - 17. october 2014, Mojmírovce, Slovak Republic, WOS, 514-520, (2014)

2. D. Vokounová, J. Kopaničová, Can I beopened? Central and EasternEurope in thechanging business environment. International jointconference. Central and EasternEurope in thechanging business environment : proceedings of 16th internationaljointconference : may 27, 2016, Prague, CzechRepublic and Bratislava, Slovakia, WOS, 347-355 (2016)

3. D. Vokounová, Generation Y - HealthRelatedAttitudes and Behaviour. Central and EasternEurope in theChanging Business Environment. International JointConference. Central and EasternEurope in theChanging Business Environment : Proceedings of 18th International JointConference : May 25, 2018, Bratislava, Slovakia and Prague, CzechRepublic, WOS,467-476 (2018)

4. G. Dubcová, D. Gajdová, K. Grančičová, Evaluation of the functioning system of thesocial and solidarity economy in Slovakia. International conference on new challenges 
in management and organization: organization and leadership. ProcediaSocial and BehavioralSciences : the 3rd International conference on new challenges in management and organization: organization and leadership, 2 May 2016, Dubai, UAE. - [s.l.] : Elsevier, WOS, 230, 254-263 (2016)

5. D. Hrušovská, Nové trendy v spotrebitel'skom správaní. Aktuálne problémy podnikovej sféry : zbornik vedeckých prác, WOS, 143-148 (2012)

6. D. Hrušovská, Vnímanie prieskumu trhu z hl'adiska podnikov v Slovenskej republike. Podnikanie a konkurencieschopnost' firiem 2010 : zborník z medzinárodnej vedeckej konferencie organizovanej v rámci podujati $k$ 70. výročiu založenia Ekonomickej univerzity v Bratislave, WOS, 108-111 (2010)

7. G. Dubcová, K. Grančičová, D. Hrušovská, Marketing performance assessment in businesses in Slovakia. ISCOBEMM 2017, WOS, 56-64 (2017)

8. D. Hrušovská, Stratégie prístupu k zákazníkovi - vnímanie hodnoty. Aktuálne problémy podnikovej sféry 2013 : [recenzovaný] zborník vedeckých prác. WOS, 187-192 (2013)

9. D. Hrušovská. Systémy vyhodnocovania dotazníkov. Aktuálne pohlady na konkurencieschopnost' a podnikanie - nové výzvy : zborník [recenzovaných] vedeckých prác, WOS, 173-177 (2011)

10. R. Madlenak, L. Madlenakova, MULTI-CRITERIA EVALUATION OF E-SHOP METHODS OF DELIVERY FROM THE CUSTOMER'S PERSPECTIVE TRANSPORT PROBLEMS, WOS, 15, 5-14 (2020)

11. M. Pechota, M. Matuskova, L. Medlenakova, The trend of cost of universal services provided by national postal operator and correlation between price of letter mail and amount of sentlettermails in Slovakia. 12TH INTERNATIONAL SCIENTIFIC CONFERENCE OF YOUNG SCIENTISTS ON SUSTAINABLE, MODERN AND SAFE TRANSPORT, WOS, 192, 574-579 (2017)

12. P. Kolarovszki, Z. Kolarovszka, L. Medlenakova, MULTIMEDIA AS A SUPPORT FOR INTERACTIVE LEARNING PROCESSES . EDULEARN16: 8TH INTERNATIONAL CONFERENCE ON EDUCATION AND NEW LEARNING TECHNOLOGIES,WOS, 2126-2133 (2016)

13. R. Medlenak, L. Medlenakova, THE GLOBAL IMPACT OF E-MARKETING STRATEGIES ON SME IN THE SEGMENT OF TOURISTIC SERVICES . GLOBALIZATION AND ITS SOCIO-ECONOMIC CONSEQUENCES, 16TH INTERNATIONAL SCIENTIFIC CONFERENCE PROCEEDINGS, PTS I-V, 12351243 (2016)

14. R. Medlenak, L. Medlenakova, L. Svedlenka, Analysis of WebsiteTrafficDependence on Use of Selected Internet Marketing Tools. 2ND GLOBAL CONFERENCE ON BUSINESS, ECONOMICS, MANAGEMENT AND TOURISM,WOS, 123-128, 23 (2015)

15. M. Maciejewski, Ch. Ratcliff, K. Næss, Spotrebitel'ská politika: zásady a nástroje. ONLINE, Available

from: https://www.europarl.europa.eu/factsheets/sk/sheet/46/spotrebitelska-politika-zasady-anastroje.

16. European Commission, Consumer conditions scoreboard: consumers at home in the single market - 2019 edition. ONLINE. Available from: https://ec.europa.eu/info/publications/consumer-conditions-scoreboard-consumershome-single-market-2019-edition_sk

17. European Commission, Opatrenia na ochranu spotrebitel'a, ONLINE. Available from: https://www.europarl.europa.eu/factsheets/sk/sheet/47/opatrenia-na-ochranu-spotrebitel

18.Z. Laky, Bezpečnost' potravín, ONLINE. Available from: https://www.europarl.europa.eu/factsheets/sk/sheet/51/bezpecnost-potravin 